\title{
QSAR MODELING OF COMPOUNDS DERIVED FROM 1,2,3- TRIAZOLOPIPERIDINE AS DPP-4 ENZYME INHIBITORS USING SEMIEMPIRICAL AM1
}

\author{
Anjar Purba Asmara* ${ }^{*}$ Reni Silvia Nasution, and Rosi Minarty \\ Chemistry Department, Faculty of Science and Technology, Universitas Islam Negeri Ar-Raniry \\ Kopelma Darussalam, Syiah Kuala, Banda Aceh, Indonesia \\ * Correspondence: email: anjarpa@ar-raniry.ac.id
}

\begin{abstract}
This study aims to model the derived compounds of 1,2,3-triazolopiperidine using semiempirical method AM1 and determine the further derivation with the better $\mathrm{IC}_{50}$ values against DPP-4 enzyme theoretically. This research employed ChemDraw Pro 12 software for for 2D structural drawing, Hyperchem 8.0 for 3D modelling, and MLR statistical analysis for modeling QSAR equations. The semiempirical method was likely to be the appropriate platform to apply because the correlation coefficient of $\mathrm{H}^{1} \mathrm{NMR}$ chemical shift between theoretical and actual value is relatively close, 0.8891 . The multilinear regression analysis produced 4 equation models where the best one is equation 4 as detailed below:" IC $50=875.5116+\left(-7400.27^{*} \mathrm{qH} 35\right)+\left(-0.00133^{*}\right.$ Eat.is $)+\left(-3230.72^{*} \mathrm{qN} 23\right)+$ $\left(3.30277^{*} \mu\right) " n=25 ; r^{2}=0.594 ;$ Adjusted $r^{2}=0.486$; PRESS $=1.2 \times 10^{4}$. Finally, the theoretically promising substituent was $-\mathrm{CN}$ possessing $\mathrm{IC}_{50}$ value $=1.61 \mathrm{nM}$.
\end{abstract}

Keywords: triazolopiperidine derivatives, diabetes mellitus, DPP-4 inhibitor, QSAR

\section{INTRODUCTION}

QSAR (quantitative structure and activity relationship) has been designed to quantify a consistent relationship between molecular skeleton and its biological activity resulting an opportunity to evaluate the properties of new materials compared to a series of molecules being modeled [1,2]. The QSAR method can also allow chemists working in synthetic field to improve their desired products performance by modelling the molecules through appropriates approach $[3,4]$. Therefore, validating methods applied in a computational project is a vital step that mainly drive the accuracy of the output.
Generally, validation of computer-assisted modelling methods in such field is likely to be carried-out by comparing the computed data with the experimental observation [5]. One of the reliable approach is comparison the chemical shift value of nuclear magnetic resonance (NMR) between calculated and actual data. Through statistical analysis, the most appropriate method could be determined by observing the correlation coefficient $\left(r^{2}\right)$ number [6].

QSAR seems to be powerful tool for predicting drug compounds and the efficacy for treating deadly diseases like type 2 diabetes mellitus (T2DM). Diabetes mellitus 
is of metabolic diseases characterized by hyperglycemia due to a deficiency of insulin secretion, insulin resistance, or both $[7,8,9$, 10]. In T2DM case, the causes may vary from the dominant insulin resistance accompanied by relative insulin deficiency to the dominant decrease of insulin secretion accompanied by insulin resistance $[8,9,10]$.

Currently, one of the most effective oral antidiabetic therapies is by inhibiting the enzyme dipeptidyl peptidase-4 (DPP-4), the main inactivator of the degradation of glucagon like peptide-1 (GLP-1) and glucosedependent insulinotropic peptide (GIP). Scientific report shows that DPP-4 inhibitors appear to be effective in controlling blood glucose levels without causing weigh gain [6]. Sitagliptin, saxagliptin, vildagliptin and linagliptin are DPP-4 inhibitors available for the treatment of T2DM in Indonesia and many other countries $[11,12,13]$. However, those drugs could cause runny or stuffy nose, sore throat, headache, backache, stomachache, diarrhea, constipation, hypoglycemia, weakness, drowsiness, and blurred vision. To reduce these side effects, the development of 1,2,3triazolopiperidine compounds, the main skeleton of sitagliptin, needs to be done by modifying the structure with the QSAR assistance $[11,12,13]$

Such research has been carried-out on the compounds through the correlation of their structure and descriptor properties with experimental activities. Modeling the triazolopiperazin amide derivatives, similar compounds to 1,2,3-triazolopiperidine, has been accomplished using the semiempirical method [14]. In the term of time consuming, the method appears to be more efficient than ab-initio in the design of drug compounds. The research suggests that further studies of DPP-4 inhibitor compounds need to be conducted especially for other compounds which inhibitory mechanism and structure resemble triazolopiperazin compounds.

\section{METHODS}

The structure of 1,2,3-triazolopiperidine derivatives and their activity $\left(\mathrm{IC}_{50}\right)$ were taken from [12]. This study employed a computer device with OS Windows 2010, RAM 4 GB DDR3L-1600, Hard Drive 500 GB. The softwares were ChemDraw Pro 12, Hyperchem 8.0, SPSS 21, and Microsoft Excel.

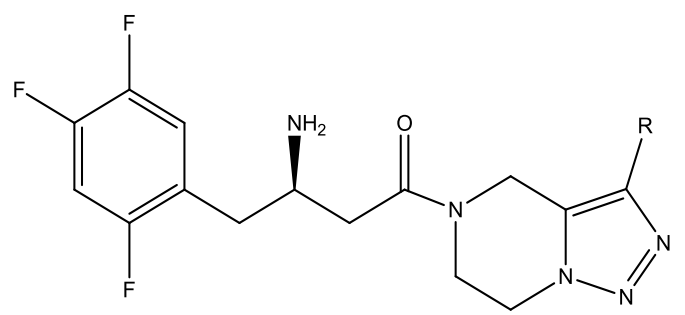

Figure 1. The main structure of 1,2,3-triazolopiperidine.[15]

\section{Geometry optimization and predictor calculations}

A total of 18 derivatives of $1,2,3$ triazolopiperidine were randomly selected $(2$, 3, 5, 6-19, 21-24) (Table 1). A 2D structure was made using the ChemDraw Pro 12 then exported to Hyperchem 8.0 for structure optimization and calculating the required parameters. The optimized geometry represents the most stable feature.

\section{Calculation of electronic and molecular parameters}

A single point calculation was performed with the output data collected in the recording file (file.log) to give energy and net atomic 
charge data. Data of partial atomic charge, surface area, volume, hydration energy, $\log \mathrm{P}$, molar refractivity, molecular polarizability and molecular mass can be seen in the QSAR properties of the Hyperchem 8.0 program.

Table 1. Substituent list and bioactivity data of 1,2,3-triazolopiperidine series

\begin{tabular}{|c|c|c|c|c|c|}
\hline No & $\mathrm{R}$ & $\mathrm{IC}_{50^{\mathrm{a}}}(\mathrm{nM})$ & No & $\mathrm{R}$ & $\mathrm{IC}_{50^{\mathrm{a}}}(\mathrm{nM})$ \\
\hline 1. & $\mathrm{H}$ & 89,50 & 14. & Ph-4-CONH 2 & 36,43 \\
\hline 2. & $\mathrm{CH}_{3}$ & 77,06 & 15. & $\mathrm{Ph}-4-\mathrm{CONMe} 2$ & 26,64 \\
\hline 3. & $\mathrm{CF}_{2} \mathrm{H}$ & 22,53 & 16. & $\mathrm{Ph}-4-\mathrm{CO}_{2} \mathrm{Me}$ & 12,40 \\
\hline 4. & $\mathrm{CF}_{3}$ & 50,66 & 17. & $\mathrm{Ph}-4-\mathrm{COOH}$ & 33,78 \\
\hline 5. & $\mathrm{CO}_{2} \mathrm{Me}$ & 15,09 & 18. & $\mathrm{Ph}-4-\mathrm{SO}_{2} \mathrm{Me}$ & 33,17 \\
\hline 6. & $\mathrm{CO}_{2} \mathrm{NH}_{2}$ & 29,92 & 19. & 4-Pyr & 28,60 \\
\hline 7. & $\mathrm{CO}_{2} \mathrm{NMe}_{2}$ & 52,34 & 20. & 2-Pyr & 33,25 \\
\hline 8. & $\mathrm{Ph}$ & 37,54 & 21. & & 15,80 \\
\hline 9. & $\mathrm{Ph}-4-\mathrm{F}$ & 45,20 & 22. & & 26,17 \\
\hline 10. & $\mathrm{Ph}-4-\mathrm{Cl}$ & 46,89 & 23. & & 22,76 \\
\hline 11. & $\mathrm{Ph}-4-\mathrm{CF}_{3}$ & 75,35 & 24. & & 47,27 \\
\hline 12. & Ph-4-CN & 30,03 & 25. & & 17,83 \\
\hline 13. & $\begin{array}{l}\mathrm{Ph}-3- \\
\mathrm{CO}_{2} \mathrm{Me}\end{array}$ & 46,61 & & & \\
\hline
\end{tabular}

3. Calculation of ${ }^{1} \mathrm{H}$ NMR $\delta$ of the compounds with semiempirical AM1 method

The optimized structures were then analyzed using proton NMR chemical shift values $(\delta)$ and compared with experimental data obtained from [9] . In the program, the structure of 1,2,3-triazolopiperidine derivatives was left-clicked to select compute menu then followed by NMR invoke. In the new page, setup was clicked then select $\mathrm{H}$ to start the calculation.

\section{QSAR analysis using multiple linear regression analysis (MLR)}

The study used MLR analysis with forward method in SPSS 21 program. The independent variables were electronic and molecular parameters obtained from the 
file.log and QSAR properties, while the dependent variable was $\mathrm{IC}_{50}$ values of the 1,2,3-triazolopiperidine derivatives.

5. Determination of the best QSAR equation model using electronic and molecular parameters

The best model determined from the the QSAR analysis was gained by comparing its $\mathrm{IC}_{50}$ value to the experimental biological activity. This can be achieved from the correlation coefficient $\left(r^{2}\right)$ of the curve.

6. Designing new compounds through modification of type and position of substituents

Modeling new compounds by modifying new substituents were generated through the selected equation to predict their $\mathrm{IC}_{50}$ value. According to [12], electronegative substituent groups $\left(\mathrm{F}, \mathrm{Cl}, \mathrm{CF}_{3}\right.$ and $\left.\mathrm{CN}\right)$ can increase the inhibitory property of these compounds. The positioning substituent focused on the active side of five-cycled ring due to the dense electron in the site.

\section{RESULTS AND DISCUSSION}

\section{Validation of the method}

The outcome of method validation is shown in Figure 2. From the $\delta$ data of proton NMR, the $r^{2}$ of the AM1 method has a relatively close to one. Statistically, this shows that the method met the required value of a validated parameter. Moreover, the AM1 method could be considered as the accurate approach to compute and model organic molecules $[16,17,18]$.

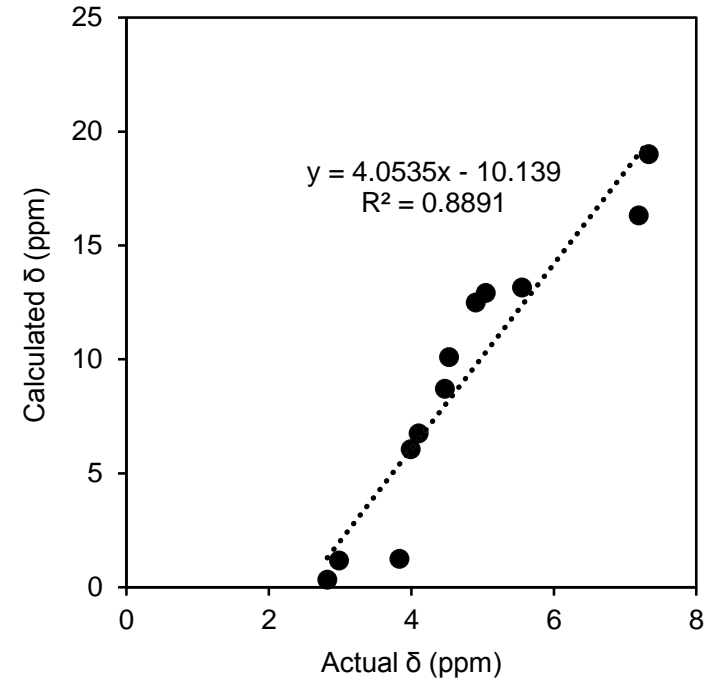

Figure 2. A curve illustrating the relationship between predictive and actual $\delta$

\section{QSAR analysis data}

The resulted QSAR equation of AM1 is presented in Table 2. Based on the PRESS values, equation 4 and 5 could be taken into account as the proper model due to the lower gaps between predictive and the experiment value indicating the reliable model for computational purposes $[18,19,20]$.

From figure 3 , model 4 could be considered as the best equation because of its slope value. The equation shows that the main descriptor is the bipolar moment $(\mu)$ indicated from the highest coefficient value. It refers to a potential difference between positive and the negative charge of the centre of atom. It is reasonable as the main descriptor due to the presence of conjugated ring where the substituents are located. The vital role of the conjugation seems to contribute at designing new modification. Meaningly, those with electronic attracting capacity are taken into account as the potential substituents providing a better inhibition. 
Table 2. Proposed QSAR model of AM1 method resulted from MLR analysis

\begin{tabular}{|c|c|c|c|c|c|c|c|}
\hline Model & Variable & $r^{2}$ & Adjusted $r^{2}$ & $F_{\text {calculation }}$ & $\mathrm{F}_{\text {table }}$ & $\mathrm{F}_{\text {cal. }} / \mathrm{F}_{\mathrm{tab}}$ & PRESS \\
\hline 1 & $\mathrm{qH} 35$ & 0.25 & 0.208 & 5.994 & 5.317 & 1.127 & $6.2 \times 10^{4}$ \\
\hline 2 & $\mathrm{qH} 35$, Eat.is, & 0.446 & 0.381 & 6.836 & 3.591 & 1.903 & $11 \times 10^{4}$ \\
\hline 3 & $\mathrm{qH} 35$, Eat.is, qN23 & 0.538 & 0.451 & 6.205 & 3.238 & 1.916 & $6.3 \times 10^{4}$ \\
\hline 4 & $\mathrm{qH} 35$, Eat.is, qN23, $\mu$, & 0.594 & 0.486 & 5.489 & 3.055 & 1.796 & $1.2 \times 10^{4}$ \\
\hline 5 & $\begin{array}{l}\text { qH35, Eat.is, qN23, } \mu, \\
\text { qN22, }\end{array}$ & 0.783 & 0.705 & 10.084 & 2.958 & 3.409 & $1.5 \times 10^{4}$ \\
\hline 6 & $\begin{array}{l}\text { qH35, Eat.is, qN23, } \mu, \\
\text { qN22, } \mathrm{CC} 20\end{array}$ & 0.816 & 0.732 & 9.637 & 2.915 & 3.305 & $16 \times 10^{4}$ \\
\hline 7 & $\begin{array}{l}\text { qH35, Eat.is, qN23, } \mu, \\
\text { qN22, qC20, MW }\end{array}$ & 0.843 & 0.751 & 9.172 & 2.913 & 3.148 & $36 \times 10^{4}$ \\
\hline
\end{tabular}
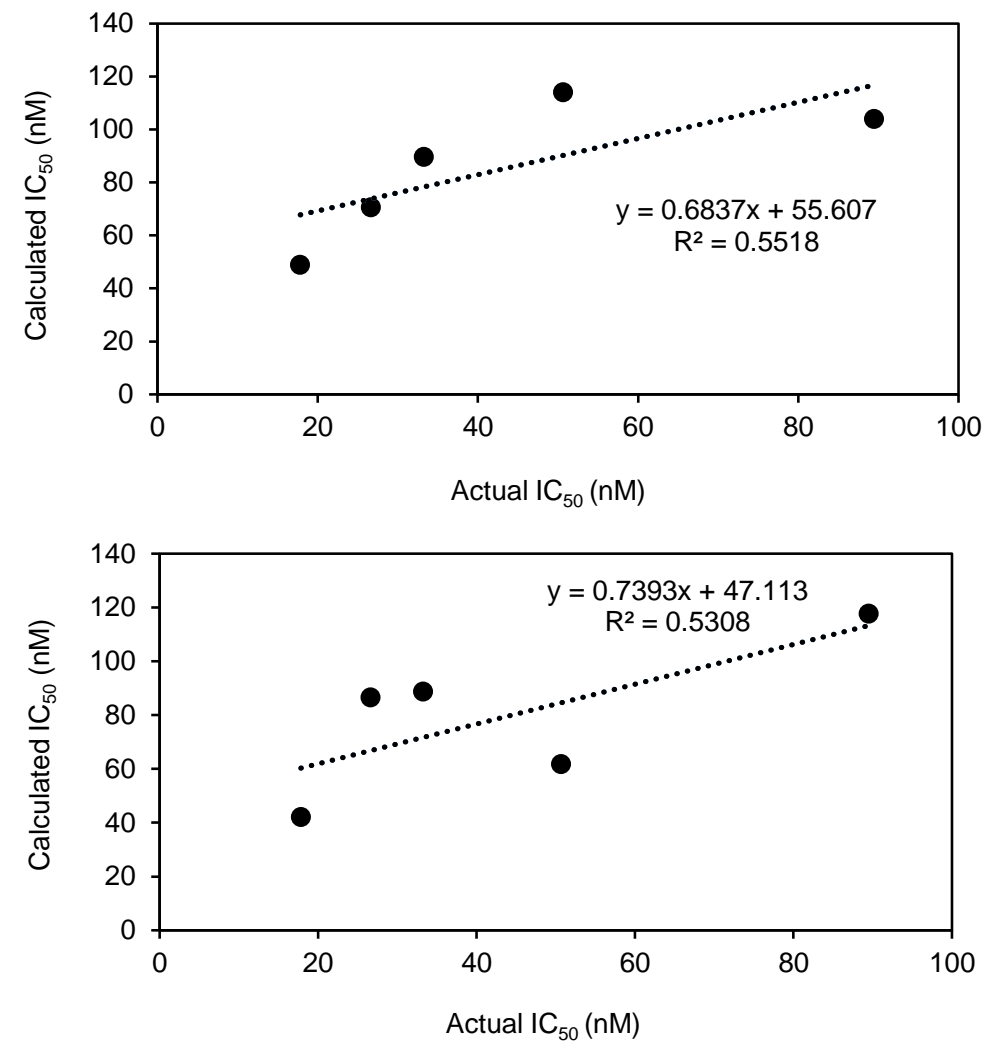

Figure 3. Curves showing a relationship between predictive values of $I C_{50}$ from model 4 (above) and model 5 (below) and actual values of the bioactivity

It can be estimated that the active antidiabetic compounds seem to own high $\mu$ coefficient values. The equation can be expressed as:

$$
\begin{aligned}
\mathrm{IC}_{50}= & 875,5116+\left(-7400,27^{*} \mathrm{qH} 35\right)+(- \\
& \left.0,00133^{*} \text { Eat.is }\right)+\left(-3230,72^{*}\right. \\
& \mathrm{qN} 23)+\left(3,30277^{*} \mu\right) \\
\mathrm{n}=25 ; & r^{2}=0,594 ; \text { adjusted } r^{2}=0,486 ; \text { PRESS } \\
= & 1,2 \times 10^{4}
\end{aligned}
$$

\section{Designing new derivatives}

As the best QSAR equation, model 4 was applied to design new compounds and predict their biological activity. The calculated parameters were $\mathrm{qH} 35$, Eat.is, qN23 and $\mu$. The $\mathrm{IC}_{50}$ values of the proposed compounds resulted from the model can be seen in the Table 3. 
Table 3. Calculated $\mathrm{IC}_{50}$ list of proposed derivatives of 1,2,3-triazolopiperidine using model 4

\begin{tabular}{|c|c|c|}
\hline No & $\mathrm{R}$ & Calculated $\mathrm{IC}_{50}(\mathrm{nM})$ \\
\hline 26. & $-\mathrm{NH}_{2}$ & 117.6376 \\
\hline 27. & $-\mathrm{CH}_{2} \mathrm{CH}_{3}$ & 62.85529 \\
\hline 28. & $-\mathrm{CH}_{2} \mathrm{CH}_{2} \mathrm{CH}_{3}$ & 69,23759 \\
\hline 29. & $-\mathrm{CO}_{2} \mathrm{CH}_{2} \mathrm{CH}_{3}$ & 29.24463 \\
\hline 30. & $-\mathrm{Br}$ & 26.90709 \\
\hline 31. & $-\mathrm{CN}$ & 1.614839 \\
\hline 32. & $-\mathrm{Cl}$ & 21.08032 \\
\hline 33. & $-\mathrm{CH}_{2} \mathrm{Br}$ & 30.20057 \\
\hline 34. & $-\mathrm{CH}_{2} \mathrm{CH}_{2} \mathrm{~F}$ & 55.85733 \\
\hline 35. & $-\mathrm{CH}_{2} \mathrm{CN}$ & 13.76882 \\
\hline $\begin{array}{l}36 . \\
37 .\end{array}$ & $\begin{array}{l}-\mathrm{CH}_{2} \mathrm{Cl} \\
-\mathrm{C}(\mathrm{Cl})_{2}\end{array}$ & $\begin{array}{l}33.49917 \\
25.97308\end{array}$ \\
\hline 38. & & 24.45556 \\
\hline 39. & & 65.46935 \\
\hline 40. & & 38.74836 \\
\hline 41. & & 69.73073 \\
\hline 42. & & 65.36978 \\
\hline
\end{tabular}

The new compounds designed from model 4 provide various $\mathrm{IC}_{50}$ values Figure 4. Accordingly, there is one compound possessing the most excellent inhibitory activity value theoretically of 1.61 , namely compound 31 Table 3. The CN-substituted derivative offers a relatively strong hydrogen bonding activity linked to the properties of the substituent as an electronegative and nonbulky group [21]. On the other hand, the compound no 26 with $\mathrm{IC}_{50}$ value $>89.50$ might be related to the $\mathrm{NH}_{2}$ group as a strong electron-withdrawing as well as medium size substituent. It might result in interference of interaction between the compound and the active site of the enzyme leading to weaker activity.

DPP 4 enzyme is the responsible player in the GLP-1/GIP-associated insulin secretion in pancreas. The enzyme cleaves the peptide bonding if the incretins using its active site. The active region of the enzyme can be classified as five sites, namely S2 extensive, S2 subsite, S1 subsite, S01 subsite, and S02 subsite [22]. In details, the composition of them is described in Table 4.

Table 4. List of identified protein composed active site of DPP-4 enzyme.

\begin{tabular}{|c|c|c|}
\hline No & Active sites & Amino acids \\
\hline 1 & $\begin{array}{l}\text { S2 ext. (S2 } \\
\text { extensive) }\end{array}$ & $\begin{array}{c}\text { Val207, Ser209, Phe357, } \\
\text { Arg358 }\end{array}$ \\
\hline 2 & S2 subsite & $\begin{array}{l}\text { Arg125, Phe357, Arg358, } \\
\text { Glu205, Glu206, Arg669 } \\
\text { Ser630, Val656, Trp659, }\end{array}$ \\
\hline 3 & S1 subsite & $\begin{array}{c}\text { Tyr662, Tyr666, Val711, } \\
\text { Asn710 }\end{array}$ \\
\hline 4 & S'1 subsite & $\begin{array}{c}\text { Phe357, Tyr547, Pro550, } \\
\text { Ser630, Tyr631, Tyr666 }\end{array}$ \\
\hline 5 & S'2 subsite & $\begin{array}{c}\text { Tyr547, Trp629, Ser630, } \\
\text { His740 }\end{array}$ \\
\hline
\end{tabular}

A well-accepted explanation with regard to the inhibition of the enzyme has confirmed a crucial role of the hydrophobic interaction and hydrogen bonding among DPP-4 and its inhibitors [23]. According to [24], physical interaction could play other roles in the case such as T-shaped, salt bridge, and cation channels. However, different inhibitor tends to exhibit different mode of action with hydrophobic and hydrogen bonding as the main key factor in the activity. 


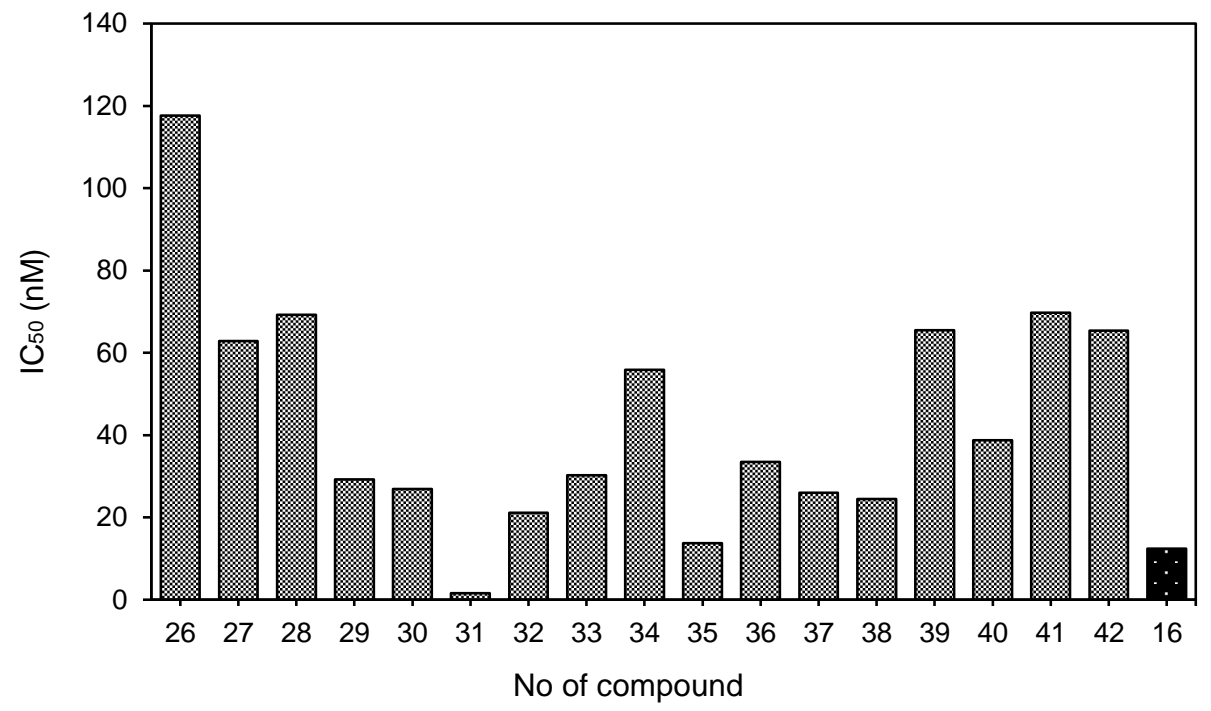

Figure 4. Graphic representation of $\mathrm{IC}_{50}$ of proposed compounds and the most actual compound

As mentioned by Arulmozhiraja and colleagues (2016), Sitagliptin, as the another derivative of triazolopiperazine, demonstrates both van der Waals dispersion and electronic interaction to bind protease sites of the enzyme. Regarding the compound 31, cyano group manifests the role of chain-like network pattern provided by atom $\mathrm{N}$ to electronically interact with hydrogen atoms in the active sites of the enzyme [25]. Such interaction may lead to stronger connection between inhibitor and the amino acids of the target.

\section{CONCLUSION}

This study confirms that semiempirical AM1 method can be applied to conduct an QSAR analysis of 1,2,3-triazolopiperidine derivatives and forecast the alternatively new derivatives owning potential bioactivity as the inhibitor of DPP 4 enzyme. The method proposed the best equation as following as:

$$
\begin{aligned}
\mathrm{IC}_{50}= & 875,5116+\left(-7400,27^{*} \mathrm{qH} 35\right)+(- \\
& \left.0,00133^{*} \text { Eat.is }\right)+\left(-3230,72^{*}\right. \\
& \mathrm{qN} 23)+\left(3,30277^{*} \mu\right)
\end{aligned}
$$

$$
\begin{aligned}
& \mathrm{n}=20 ; r^{2}=0,594 ; \text { adjusted } r^{2}=0,486 ; \text { PRESS } \\
& =1,2 \times 10^{4}
\end{aligned}
$$

Theoretically, the research offer a new compound with $-\mathrm{CN}$ as the alternative substituent to obtain the better value of the inhibitory activity. Further attempts are needed to confirm the feasibility and also the activity of the proposed species through laboratory work.

\section{REFERENCES}

[1] H. D. Pranowo, Pengantar Kimia Komputasi, Bandung: Lubuk Agung, 2011.

[2] S. B. Utomo, F. Sanubari, B. Utami, \& N. D. Nurhayati, " Analysis of a quantitative relationship between the structure and analgesic activity of meperidin derivatives using semiempirical AM1 method", JKPK (Jurnal Kimia dan Pendidikan kimia), vol. 2, no. 3, pp. 158-168, 2017.

DOI: 10.20961/jkpk.v2i3.12092

[3] M. D. Breyer," Improving productivity of modern-day drug discovery", Expert Opinion on Drug Discovery, vol. 9, no. 2, pp.115-118, 2014

DOI: $10.1517 / 17460441.2014 .870150$ 
[4] W. Hui, M. Jiang, F. Sun, S. Li, C.Y. Hse, \& C. Jin, "Screening, synthesis, and QSAR research on cinnamaldehyde-amino acid schiff base compounds as antibacterial agents. Molecules, vol. 23, no.11, 2018. DOI:10.3390/molecules23113027

[5] A. P. Asmara, Mudasir, \& D. Siswanta, "Penentuan metode komputasi untuk analisis hubungan kuantitatif struktur dan aktivitas senyawa turunan triazolopiperazin amida". Elkawnie: Journal of Islamic Science and Technology, vol. 1, no.1, pp19-30, 2015. DOI:10.22373/ekw.v1i1.515

[6] H. D. Pranowo, Kimia Komputasi. Yogyakarta: Pusat Kimia Komputasi UGM, 2000.

[7] P. N. Malani. "Harrison's Principles of Internal Medicine", JAMA. vol.308, no.17, pp. 1813-1814,2012.

DOI:10.1001/jama.308.17.1813-b

[8] C. D.A. Stehouwer \& N. C. Schaper, Therapeutic strategies in Diabetes. Oxford: Clinic.al Publishing, 2009.

[9] H. Yehuda, \& Z. Bloomgarden, “ Diabetes In Youth: A Dilemma Of Pathogenesis". Juornal Of Diabetes. Metabolic Institute of America, vol.3, no 2, pp 91-92, 2011. DOI:10.1111/j.1753-0407.2011.00127.x

[10] Roglic, Gojka. "WHO Global report on diabetes: A summary." International Journal of Noncommunicable Diseases, vol.1, no.1, pp3-8, 2016.

[11] J. J. Neumiller, L. Wood, \& R. K. Campbell, "Dipeptidyl peptidase 4 (DPP-4) inhibitors for the treatment of type 2 diabetes mellitus", Pharmacotherapy, vol. 30, no.5, pp463-484,2010.

DOI:10.1592/phco.30.5.463

[12] Z. Shan, M. Peng, H. Fan, Q. Lu, P. Lu, C. Zhao, \& Y.Chen, "Discovery of potent dipeptidyl peptidase IV inhibitors derived for the treatment of type 2 diabetes, Bioorganic \& Medicinal Chemistry Letters, vol 21, no.6, pp 1731-1735, 2011. DOI:10.1016/j.bmcl.2011.01.086
[13] S. A. El-Karim, Y. M. Syama, M. A. Nael, H. F. Ali, \& M. A. Motaleb, “ Rational design and synthesis of new tetralin-sulfonamide derivatives as potent antidiabetics and DPP-4 inhibitors: 2D\&3D QSAR, in vivo radiolabeling and bio distribution studies", Bioorganic Chemistry, vol. 81, pp. 481-493, 2018. DOI:10.1016/j.bioorg.2018.09.021

[14] A. P. Asmara, Mudasir, \& D. Siswanta, "Analisis HKSA senyawa antidiabetik turunan triazolopiperazin amida menggunakan metode semiempirik PM3. AlChemy: Journal of Chemistry, vol. 5, no. 4, pp. 106-113, 2017.

DOI:10.18860/al.v5i4.4045

[15] K. Wijaya, I. Tahir, B. Purwono, \& W. Dinni," QSAR study of flavone/flavonol analogues as the antiradical compounds based on Hansch analysis", Indonesian Journal of Chemistry, vol. 3, no. 1, pp. 48-54, 2003.

DOI:10.22146/ijc.21905

[16] F. Jensen, Introduction to Computational Chemistry. West Sussex: John Wiley \& Sons, 2007.

[17] I. Tahir \& P. Iswanto, "Hubungan kuantitatif struktur dan aktivitas antikanker senyawa turunan estradiol hasil perhitungan metode semiempiris AM1. Yogyakarta: Prosiding Seminar Nasional Kimia XV, ISSN 1410-8313, 2004.

[18] P. E. Istyastono, S. Martono, H. D. Pranowo, \& I. Tahir, "Quantitative structure-activity relationship analysis of curcumin and its derivatives as gst inhibitors based on computational chemistry calculation". Indonesian Journal of Chemistry, vol. 3, no. 3, pp. 179-186, 2003.

DOI:10.22146/ijc.21886

[19] H. D. Siswandono, Kimia Medisinal, Surabaya: Universitas Airlangga Press, 2000.

[20] G. L Patrick, An Introduction to Medicinal Chemistry, Oxford: Oxford University Press, 2013. 
[21] C. Li, M. Hanif, X. Li, S. Zhang, Z. Xie, L. Liu, B. Yang, S. Su, \& Y. Ma, "Effect of cyano-substitution in distyrylbenzene derivatives on their fluorescence and electroluminescence properties". Journal of Materials Chemistry C, vol. 4, no. 31, pp. 7478-7484, 2016.

DOI:10.1039/C6TC01886F

[22] S. Arulmozhiraja, N. Matsuo, E. Ishitsubo, S. Okazaki, H. Shimano, \& $\mathrm{H}$. Tokiwa, "Comparative Binding Analysis of Dipeptidyl Peptidase IV (DPP-4) with Antidiabetic Drugs - An $\mathrm{Ab}$ Initio Fragment Molecular Orbital Study. PLoS ONE, vol.11, no.11, 2016. DOI:10.1371/journal.pone.0166275

[23] K. Aertgeerts, S. Ye, M. G. Tennant, M. L. Kraus, J. O. E. Rogers, B. C. Sang, R. J. Skene, D. R. Webb, \& G. S. Prasad, "Crystal structure of human dipeptidyl peptidase IV in complex with a decapeptide reveals details on substrate specificity and tetrahedral intermediate formation", Protein Science, vol.13, no.2, pp. 412-421, 2004.

DOI : $10.1110 / p s .03460604$
[24] S. Q. Pantaleão, E .A. Philot, D. Resende-Lara, P. Túlio, A. N. Lima, D. Perahia, M. A. Miteva, A. L. Scott, \& K. M. Honorio, "Structural dynamics of DPP-4 and its influence on the projection of bioactive ligands", Molecules, vol. 23, no.2, pp. 490, 2018.

DOI:10.3390/molecules23020490

[25] D. Bhattacherjee, C. Basu, Q. Bhardwaj, S. Mal, S. Sahu, R. Sur, \& K. P. Bhabak, "Design, Synthesis and AntiCancer Activities of Benzyl Analogues of Garlic-Derived Diallyl Disulfide (DADS) and the Corresponding Diselenides", Chemistry Select, vol. 2. no. 24, pp. 7399-7406, 2017.

DOI:10.1002/slct.201700499 